\title{
Brain Structure and Function \\ Cellular composition characterizing postnatal development and maturation of the mouse brain and spinal cord --Manuscript Draft--
}

\begin{tabular}{|c|c|}
\hline Manuscript Number: & BSF-D-12-00094R2 \\
\hline Full Title: & $\begin{array}{l}\text { Cellular composition characterizing postnatal development and maturation of the } \\
\text { mouse brain and spinal cord }\end{array}$ \\
\hline Article Type: & Original Article \\
\hline Keywords: & Neuron number; quantification; maturation; isotropic fractionator; adolescence \\
\hline Corresponding Author: & $\begin{array}{l}\text { Charles Roger Watson, MD } \\
\text { Curtin University } \\
\text { Perth, WA AUSTRALIA }\end{array}$ \\
\hline \multicolumn{2}{|l|}{$\begin{array}{l}\text { Corresponding Author Secondary } \\
\text { Information: }\end{array}$} \\
\hline Corresponding Author's Institution: & Curtin University \\
\hline \multicolumn{2}{|l|}{$\begin{array}{l}\text { Corresponding Author's Secondary } \\
\text { Institution: }\end{array}$} \\
\hline First Author: & YuHong Fu, MD PhD \\
\hline \multicolumn{2}{|l|}{ First Author Secondary Information: } \\
\hline \multirow[t]{5}{*}{ Order of Authors: } & YuHong Fu, MD PhD \\
\hline & Zoltan Rusznak, MD PhD \\
\hline & Suzana Herculano-Houzel, PhD \\
\hline & Charles Roger Watson, MD \\
\hline & George Paxinos, PhD DSc \\
\hline \multicolumn{2}{|c|}{ Order of Authors Secondary Information: } \\
\hline Abstract: & $\begin{array}{l}\text { The process of development, maturation, and regression in the central nervous system } \\
\text { (CNS) are genetically programmed and influenced by environment. Hitherto, most } \\
\text { research efforts have focused on either the early development of the CNS or the late } \\
\text { changes associated with aging, whereas an important period corresponding to } \\
\text { adolescence has been overlooked. In this study we searched for age-dependent } \\
\text { changes in the number of cells that compose the CNS (divided into isocortex, } \\
\text { hippocampus, olfactory bulb, cerebellum, 'rest of the brain', and spinal cord) and the } \\
\text { pituitary gland in 4-40-week-old C57BL6 mice, using the isotropic fractionator method } \\
\text { in combination with neuronal nuclear protein (NeuN) as a marker for neuronal cells. } \\
\text { We found that all CNS structures, except for the isocortex, increased in mass in the } \\
\text { period of } 4-15 \text { weeks. Over the same period, the absolute number of neurons } \\
\text { significantly increased in the olfactory bulb and cerebellum while non-neuronal cell } \\
\text { numbers increased in the 'rest of the brain' and isocortex. Along with the gain in body } \\
\text { length and weight, the pituitary gland also increased in mass and cell number, the } \\
\text { latter correlating well with changes of the brain and spinal cord mass. The majority of } \\
\text { the age-dependent alterations (e.g., somatic parameters, relative brain mass, number } \\
\text { of pituitary cells, and cellular composition of the cerebellum, isocortex, rest of the brain, } \\
\text { and spinal cord) occur rapidly between the } 4 \text { th and } 11 \text { th postnatal weeks. This period } \\
\text { includes murine adolescence, underscoring the significance of this stage in the } \\
\text { postnatal development of the mouse CNS. }\end{array}$ \\
\hline
\end{tabular}




\title{
Cellular composition characterizing postnatal development and maturation of the
}

\section{mouse brain and spinal cord}

YuHong Fu ${ }^{\mathrm{a}, \mathrm{b},{ }^{*}}$, Zoltán Rusznák ${ }^{\mathrm{a},{ }^{*}}$, Suzana Herculano-Houzel ${ }^{\mathrm{c}, \mathrm{d}}$, Charles Watson ${ }^{\mathrm{a}, \mathrm{e}}$, and George Paxinos ${ }^{\mathrm{a}, \mathrm{b}}$

\author{
${ }^{a}$ Neuroscience Research Australia, Sydney, NSW 2031, Australia \\ ${ }^{b}$ The University of New South Wales, Sydney, NSW 2052, Australia \\ 'Instituto de Ciências Biomédicas, Universidade Federal do Rio de Janeiro, Brasil \\ ${ }^{d}$ Instituto Nacional de Neurociência Translacional, São Paulo, Brasil \\ ${ }^{e}$ Faculty of Health Science, Curtin University, Perth, WA 6845, Australia
}

*Y. Fu and Z. Rusznák have made an equal contribution to this paper

Corresponding author: Dr Charles Watson Curtin University, Shenton Park Health Research Campus, GPO Box U1987, Perth WA Australia 6845 Tel: +61 892661640

fax: +61 892661650

E-mail address: c.watson@curtin.edu.au 


\section{ABBREVIATIONS}

CNS Central nervous system

DAPI 4',6-diamidino-2-phenylindole

DG Dentate gyrus

NeuN Neuronal nuclear protein

PBS Phosphate buffered saline

W4 4-week-old mice

W15 15-week-old mice

W40 40-week-old mice 


\begin{abstract}
The process of development, maturation, and regression in the central nervous system (CNS) are genetically programmed and influenced by environment. Hitherto, most research efforts have focused on either the early development of the CNS or the late changes associated with aging, whereas an important period corresponding to adolescence has been overlooked. In this study we searched for age-dependent changes in the number of cells that compose the CNS (divided into isocortex, hippocampus, olfactory bulb, cerebellum, 'rest of the brain', and spinal cord) and the pituitary gland in 4-40-week-old C57BL6 mice, using the isotropic fractionator method in combination with neuronal nuclear protein $(\mathrm{NeuN})$ as a marker for neuronal cells. We found that all CNS structures, except for the isocortex, increased in mass in the period of 4-15 weeks. Over the same period, the absolute number of neurons significantly increased in the olfactory bulb and cerebellum while non-neuronal cell numbers increased in the 'rest of the brain' and isocortex. Along with the gain in body length and weight, the pituitary gland also increased in mass and cell number, the latter correlating well with changes of the brain and spinal cord mass. The majority of the age-dependent alterations (e.g., somatic parameters, relative brain mass, number of pituitary cells, and cellular composition of the cerebellum, isocortex, rest of the brain, and spinal cord) occur rapidly between the $4^{\text {th }}$ and $11^{\text {th }}$ postnatal weeks. This period includes murine adolescence, underscoring the significance of this stage in the postnatal development of the mouse CNS.
\end{abstract}

Keywords: Neuron number $\bullet$ Quantization $\bullet$ Maturation $\bullet$ Isotropic fractionator $\bullet$ Adolescence 


\section{Introduction}

The development of the brain and spinal cord begins in the early prenatal life and most of the neurons of the adult central nervous system (CNS) are born during the prenatal and early postnatal periods (Altman 1969a, b; Bayer 1980a, b, 1989; Paxinos et al. 2007; Bandeira et al. 2009). The development and maturation of the CNS, together with its regression that occurs at later stages, are continuous processes from the very early prenatal period until death. A number of studies have dealt either with regional changes of the neuronal number during postnatal development of the mouse brain (Haddara 1956; Lyck et al. 2007) or have focused on age-related changes affecting the cellular organization of the rat (Bandeira et al. 2009). However, we lack information on the precise cellular composition of the mouse CNS (e.g., number, density, and proportion of neuronal and nonneuronal cells accommodated by the various parts) during the period from post-weaning (3-4 weeks postnatal) to adulthood. This period constitutes the murine period of adolescence, a particularly important stage in the postnatal development, characterized by robust changes in hormonal status, body size, and behavior (Drickamer 1981; Vandenbergh 1987; Fox et al. 2006).

There are marked differences in behavior between adolescent and adult mice (Koek et al. 2012; Quoilin et al. 2012), which might be reflected in the structure of the CNS. On the basis of functional changes taking place in this period, it is reasonable to suspect that there must be modifications affecting the cellular organization of the CNS during adolescence. However, there is only one study elaborating on changes associated with postnatal development of the brain and it was conducted on rats (Bandeira et al. 2009). In addition, we found no data in the literature aimed at describing changes in the number of spinal cord cells during the postnatal life in general let alone during adolescence. Considering the widespread use of mice (both wild-type and transgenic strains) in a wide range of neuroanatomical and neurophysiological studies, as well as the significance of puberty in the development and maturation of the human brain (Sisk and Foster 2004), we thought it would be useful to investigate changes in the cellular composition of the mouse CNS in this developmental stage.

We have, therefore, investigated changes in the cellular organization of the mouse CNS from early postnatal life ( 4 weeks) to adulthood (up to 40 weeks). In the past, most studies attempting to describe agerelated changes in the CNS focused on neuronal density, rather than actual neuronal numbers (e.g., Flood and Coleman 1988). In most of these reports, stereological techniques were used to determine cell numbers of relatively isotropic regions. However, with the introduction of the isotropic fractionator method (HerculanoHouzel and Lent 2005), it became possible to assess changes affecting the total, neuronal, and non-neuronal cell 
numbers in either the entire CNS or in any region of interest in a resource-effective manner. In the present study, the isotropic fractionator technique was used to investigate changes affecting the number and density of cells in the mouse CNS from 4 to 40 weeks. We aimed to determine whether there is a watershed period which would separate immature and adult-like cellular organization in the CNS, and hence which could be regarded as marking the end of the postnatal development of the mouse CNS. 


\section{Materials and methods}

\section{Animals}

Male C57BL/6J mice $(n=30)$ were obtained from the Animal Resources Centre (Canning Vale, WA, Australia). Five mice from different litters were studied at each of the following ages: 4, 6, 8, 11, 15, and 40 weeks. All experiments were approved by the Animal Care and Ethics Committee of The University of New South Wales (Approved ACEC No. 11/75A) and were carried out in accordance with the relevant national (Australian) and institutional guidelines on the care of research animals.

\section{Perfusion and tissue dissection}

Mice were euthanized by injection of a lethal dose of pentobarbitone sodium $(0.24 \mathrm{mg} / \mathrm{g}$ body weight $)$. After the onset of anesthesia, the body mass and the body length were measured; the latter was defined as the distance between the interorbital line and the root of the tail. Mice were then perfused through the left ventricle with saline, followed by $4 \%$ paraformaldehyde prepared in phosphate buffered saline (PBS; $\left.p H 7.4,4^{\circ} \mathrm{C}\right)$. Brains and spinal cords were separated at the caudalmost level of the pyramidal decussation and removed from the skull and spine, respectively. The pituitary gland was removed from the hypophyseal fossa. The mass of each brain and spinal cord was recorded and the length of the spinal cord measured. After three weeks post-fixation, brains were dissected into five regions — olfactory bulb, cerebral cortex (principally isocortex), hippocampus, cerebellum, and 'rest of the brain' (comprising the diencephalon, mesencephalon, and axial rhombencephalon; see the topography shown in Fig. 1a). In the case of the spinal cord, the meninges and nerve rootlets were removed. At the end of the dissection, the mass of each separated structure, including the pituitary gland, was measured.

3. Quantification of the total, neuronal, and non-neuronal cell numbers

The isotropic fractionator method was used to determine the total number of cells and the total number of neuronal nuclear protein (NeuN) positive cells (Herculano-Houzel and Lent 2005). To achieve this, each block of tissue was mechanically homogenized in a dissociation solution ( $1 \%$ Triton X-100 in $40 \mathrm{mM}$ trisodium citrate) until an isotropic nuclear suspension was obtained. For the determination of the total cell number, 4',6diamidino-2-phenylindole (DAPI) dilactate (Invitrogen, Mulgrave, VIC, Australia) was added to the nuclear suspension to label all cell nuclei. Four to ten aliquots $(10 \mu \mathrm{l}$ each $)$ of nuclear suspension were loaded onto a hemocytometer and the number of cell nuclei was determined by two observers, independently, using a fluorescence microscope [Olympus BX51 (Olympus, Tokyo, Japan)] equipped with an AxioCam HRc digital 
camera (Carl Zeiss International, Oberkochen, Germany). The DAPI signal was observed using a U-MWU2 filter set (Olympus) and the cells were counted with the assistance of the counting grids that were made simultaneously visible using low intensity bright field illumination. In all cases, each observer counted 2-6 samples per suspension. After the initial four counts ( 2 from each observer), the coefficient of variation was determined. Additional counts from each observer were performed until the coefficient of variation was less than 0.15. The total number of cells of each individual region was determined on the basis of the total volume and average cell number of the homogenized samples.

To determine the total number of neurons in each structure, NeuN-specific labeling of the cell nuclei was employed. NeuN is a sensitive and specific neuronal marker (Mullen et al. 1992), which labels nearly all neuronal nuclei, with some exceptions (notably Purkinje cells and mitral cells of the olfactory bulb; see Mullen et al. 1992; Wolf et al. 1996). Since the relative number of these NeuN negative neurons is very small (Royet et al. 1998; Wittmann and McLennan 2011), the errors introduced by their absence from the relevant NeuN counts had no appreciable effects on the overall results in previous studies (Herculano-Houzel and Lent 2005; Bandeira et al. 2009). Therefore, in this study, we consider the NeuN positive cells to be neurons and NeuN negative cells to be non-neurons (mostly glia).

To obtain the NeuN positive cell number in each structure, the NeuN positive cell ratio was examined as follows. The DAPI-labeled suspension (1 ml) was centrifuged, washed with PBS, and incubated with a mouse anti-NeuN IgG (1:500; MAB377, Chemicon Australia, Boronia, VIC) at $4{ }^{\circ} \mathrm{C}$ for $12 \mathrm{hrs}$. After three washes with PBS, Alexa Fluor ${ }^{\circledR} 594$ goat anti-mouse antibody (1:300; A11032, Invitrogen) was applied at room temperature for $2 \mathrm{hrs}$ followed by three washes in PBS to stop the reaction. Using $8 \mu \mathrm{l}$ of the suspension allowed the formation of a single layer of the cell suspension in the counting chamber. The samples were examined by two observers, under the fluorescence microscope, independently. To determine the NeuN positive cell ratio, at least 500 DAPI-labeled cell nuclei were counted in each loading (microscopic images of NeuN negative and NeuN positive cell nuclei are shown in Fig. 1b). The NeuN positive nuclei were counted in every visual field by switching between the U-MWU2 and XF102-2 (Omega Optical, Inc., Brattleboro, VT, USA) filter sets. Either observer counted 2-4 loadings of each sample. The number of NeuN positive cells was calculated from the NeuN positive cell ratio and the total cell number.

<Fig. 1 is about to be here>

4. Parameters characterizing age-dependent changes affecting the mouse CNS

In the present work, age-dependence of the following parameters was measured in each part of the mouse CNS: 
(1) mass; (2) total cell number; (3) number of NeuN positive nuclei; (4) proportion of NeuN positive cell nuclei (obtained as the number of NeuN positive cell nuclei/number of all cell nuclei); (5) number of NeuN negative cell nuclei (obtained as the total number of cell nuclei less the number of NeuN positive nuclei); (6) ratio of NeuN negative / NeuN positive cell nuclei; (7) Neuron density (expressed as NeuN positive cell number/mg tissue); and (8) non-neuron density (expressed as NeuN negative cell number/mg tissue).

Individual values belonging to the animals with the same age were pooled and the mean values were plotted as a function of postnatal age. Results are presented as mean \pm SEM.

5. Data analysis and statistics

To find whether any of the parameters showed age-dependent changes in the age period investigated, the 4 (W4), 15 (W15), and 40 weeks old (W40) groups were compared using one-way ANOVA and Tukey post-hoc tests. The 8-, 11-, and 15-week-old groups were recruited as putative 'fully mature' (i.e., past the period of adolescence) groups; while the 4- and 6-week-old individuals were hypothesized as undergoing changes associated with murine adolescence. In contrast, W40 group was employed to see whether significant agerelated changes occurred in the 15-40 weeks period, which could indicate regression within the CNS.

Correlation between age and any other parameter was sought by determining the Pearson's and Spearman's coefficients ( $\mathrm{R}$ and $\rho$, respectively). If age-dependent changes were statistically confirmed $(p<0.05)$ and/or the trends of changes were obvious, linear regression or single exponential functions were fitted to the data as follows:

(i) Linear regression function:

$$
y=A+B x \quad(1)
$$

(ii) Single exponential function:

$$
y=y_{0}+A e^{-\frac{x}{\tau}}
$$

where $\tau$ is the time constant of the change investigated.

To highlight some of the age-dependent changes, pooled group comparisons were performed. In these instances mice aged 4-6 and 11-40 weeks were pooled and the two groups were compared using Student's $t$ test.

Statistical analyses and fittings were performed using the IBM SPSS Statistics (v19; IBM Corporation, Armonk, NY, USA) and Origin 6.1 graphing and data analysis programs (OriginLab Corporation, Northampton, MA, USA). 


\section{Results}

1. Age-dependent changes of somatic parameters, CNS mass, and relative brain mass in the 4-40-week period We first investigated age-dependent changes affecting basic somatic parameters, such as the body mass, body length, and the length of the spinal cord. As demonstrated in Figs. 2a-2b, strongly significant differences could be observed when parameters obtained from W4 were compared to those of W15 ( $p<0.001$ in each case). In contrast, no statistically significant difference could be obtained when the W15 and W40 groups were compared to each other. The age-dependence of these parameters could be fitted to a single exponential function, with time constants $(\tau)$ of $3.21,5.11$, and 4.07 weeks for the body length, spinal cord length, and body mass, respectively.

In the isocortex, there was no significant difference between the masses of W4 (181 $\pm 8 \mathrm{mg})$, W15 (178 $\pm 3 \mathrm{mg})$, or W40 (191 $\pm 3 \mathrm{mg})$, but a statistically significant mass gain was observed in all other areas (Figs. 2c-2d). The change observed in the investigated age period could be best described by a single exponential function, with time constants ranging from 2.81 weeks (cerebellum) to 9.44 weeks ('rest of the brain') (Fig. 2d).

To investigate whether the mass of either of the two major parts of CNS developed in a synchronous manner, the masses of the brain and spinal cord were plotted against each other (Fig. 2e). The resulting scatter plot showed good linear regression $(\mathrm{R}=0.821 ; p<0.001)$, indicating that the two structures gain mass in a synchronous manner.

Finally, the relative brain mass (i.e., brain mass over body mass) reduced rapidly as the mice got older and it leveled off at about 11 weeks (Fig. 2f). The age-dependent change of the relative brain mass could be characterized by a single exponential function with a time constant of 2.15 weeks.

$<$ Fig. 2 is about to be here>

\section{Age-dependent alterations characterizing the organization of the mouse CNS}

Having established the presence of age-dependent changes affecting the mass of the CNS of the mouse, we wished to determine whether these changes were accompanied by alterations in neuronal and non-neuronal cell numbers. Generally, the total numbers of the NeuN positive and NeuN negative cells in the brain showed agedependent changes $(\rho=0.470$ and $\rho=0.592$ for the NeuN positive and NeuN negative cell numbers, respectively; $\mathrm{p}<0.01$ in both cases). At 4 and 15 weeks, the mean neuronal cell number of the individual brains was $5.7 \pm 0.2 \times 10^{7}$ and $6.9 \pm 0.2 \times 10^{7}$, respectively (the difference is statistically significant; $p<0.05$ ). In 40 
week old mice, the mean neuronal number of the brain was $6.3 \pm 0.2 \times 10^{7}$, which was not significantly different from that of the 15 week old group. As for the number of non-neuronal cells, there was a statistically significant increase from $4.51 \pm 0.06 \times 10^{7}$ (W4) to $5.0 \pm 0.1 \times 10^{7}$ (W15; $p<0.05$ ). By the age of 40 weeks, the nonneuronal cell number increased to $5.3 \pm 0.1 \times 10^{7}$; an increase that was non-significant when compared to W15 ( $p=0.099)$, although it proved to be strongly significant when compared to the youngest group $(p<0.01)$.

A summary of the most important changes characterizing each of the investigated structures is presented in Table 1.

$<$ Table 1 is about to be here>

2.1. Age-dependent alterations affecting the spinal cord

The length (Fig. 2b) and mass (Fig. 2d) of the spinal cord showed age-dependent changes and both of these changes could be described by a single exponential function. While numbers of neurons did not change significantly across the ages examined, we found that the changes of length and mass were accompanied by a significant increase of the number of NeuN negative cells when week 4 was compared to week 40 (Fig. 3a; $p<0.05)$. The age-dependence of the NeuN negative cell number $(\rho=0.488, p<0.01)$ could be fitted to a single exponential function with a time constant of 2.40 weeks. An age-related addition of non-neuronal cells to the spinal cord is evidenced as a pronounced shift of the NeuN negative / NeuN positive cell number ratio (Fig. 3b), increasing from $3.15 \pm 0.17$ (at 4 weeks) to $4.1 \pm 0.2$ at 40 weeks $(p<0.01)$. The age-dependence of the change could be fitted to a linear regression function $(\mathrm{R}=0.547 ; p<0.01)$, resulting in a change of 0.023. week $^{-1}$ (Fig. 3b).

Both the NeuN negative and NeuN positive cell densities decrease significantly with age, with apparent time constants of 7.92 and 15.08 weeks, respectively (Fig. 3c). It was also revealed that neuronal (Fig. 3d) and non-neuronal cell densities (not shown) negatively correlate with the mass of the spinal cord (NeuN positive density: $\mathrm{R}=-0.809, \mathrm{~B}=-390$ cells $\cdot \mathrm{mg}^{-2} ;$ NeuN negative density: $\mathrm{R}=-0.702 ; \mathrm{B}=-700$ cells $\cdot \mathrm{mg}^{-2} ; \mathrm{p}<0.001$ in both instances).

$<$ Fig. 3 is about to be here>

2.2. Age-dependent alterations of the mouse brain

Isocortex

In the present work, the isocortex was the only CNS structure in which the mass did not show significant agedependent change (Fig. 2c). However, statistically significant increases were noted in the NeuN negative cell 
number and the NeuN negative cell density between 4 and 15 weeks (in both cases $p<0.05$ ), without an apparent change of the NeuN positive cell number or of the NeuN positive cell density (Fig. 4a-b).

The age-dependence of the NeuN negative cell number $(\rho=0.504 ; p<0.01)$ in the various age groups could be fitted to a single exponential function with a time constant of 3.96 weeks. The increase of the NeuN negative cell number is the most pronounced between weeks 6 and 11 (Fig. 4a). In addition, an age-dependent increase of the NeuN negative / NeuN positive cell number ratio could be observed between 4-15 weeks (from $2.6 \pm 0.1$ to $3.1 \pm 0.1 ; p<0.05$; Fig. 4 c) , which could be well fitted to an exponential function $(\rho=0.635$; $p<0.001 ; \tau=10.32$ weeks).

$<$ Fig. 4 is about to be here>

\section{Cerebellum}

There was an age-dependent increase of the mass (Fig. 2d) and in the number of NeuN positive cells of the cerebellum (Fig. 5a1). The mean neuronal cell number changed from $41 \pm 0.2 \times 10^{6}$ (W4) to $52 \pm 0.2 \times 10^{6}$ (W15; $p<0.01)$. The age-dependence of the NeuN positive cell number $(\rho=0.471 ; p<0.01)$ could be fitted to an exponential function giving a time constant of 2.86 weeks. In contrast, neither the NeuN negative cell number nor the cell densities showed statistically significant age-dependence (Fig. 5a1-a2). There was no significant change in the NeuN negative / NeuN positive cell number ratio either.

\section{Hippocampus}

The increasing mass of the hippocampus (Fig. 2c) was not accompanied by statistically significant increase in the numbers of NeuN positive or NeuN negative cells (Fig. 5b). The NeuN negative / NeuN positive cell number ratio did not show age-dependence either $(R=0.054 ; \rho=0.200)$, varying around a mean value of $3.17 \pm 0.10$ (including all data from 4 to 40 weeks).

\section{Olfactory bulb}

A prominent increase in the number of NeuN negative and NeuN positive cells (Fig. 5c) accompanied the increase of the olfactory bulb mass (Fig. 2c). The absolute number of the NeuN positive cells increased beyond 11 weeks of age [from $5.39 \pm 0.22 \times 10^{6}$ (W4) to $7.22 \pm 0.33 \times 10^{6}$ cells (W15); $p<0.05$ ], indicating an ongoing net genesis of neurons in this region. The age-dependent increase of NeuN positive cell number $(\rho=0.811$; $p<0.001)$ could be fitted to an exponential function, yielding a time constant of 15.04 weeks. The agedependence of the NeuN negative cell number could be better approximated by a linear function $(R=0.580$; $\mathrm{p}<0.001$ ), approximating a rate of NeuN negative cell number increase of 38,000 cells.week $^{-1}$ in the time 
period investigated.

We found no statistically significant change in the NeuN positive and NeuN negative cell densities of the olfactory bulb (week 4 vs. week 40), suggesting a more or less proportional increase of the cell numbers and the hosting tissue mass.

$<$ Fig. 5 is about to be here>

\section{The 'rest of the brain'}

The age-dependent increase of the 'rest of the brain' mass (Fig. 2d) was accompanied by a significant increase in the number of NeuN negative cells (from $15.7 \pm 0.06 \times 10^{6}$ at week 4 to $18.6 \pm 0.05 \times 10^{6}$ cells at week 15 ; $p<0.01$ ), whereas the NeuN positive cell number did not show age-dependent changes (Fig. 6a). The NeuN negative cell densities did not show age-dependence either. In contrast, the NeuN positive cell density decreased with age ( $\rho=-0.671 ; p<0.001$ ) with an apparent $\tau$ of 10.63 weeks (Fig. 6b). Although neither the difference between the 4 and 15 nor the difference between 15 and 40 weeks old groups was statistically significant, when the 4-week-old group was compared to the 40-week-old one, the reduction of the NeuN positive cell density proved to be statistically significant $(p<0.01)$.

The NeuN negative / NeuN positive cell number ratio changed with age, increasing from $2.84 \pm 0.07$ (4 weeks) to $3.75 \pm 0.19$ ( 40 weeks; $p<0.05$ ). The age-dependence of this parameter could be well fitted to a single exponential function ( $\rho=0.540 ; p<0.01$ ), with a time constant of 8.19 weeks (Fig. 6c).

<Fig. 6 is about to be here>

3. Age-dependent alterations of the pituitary gland and interdependence between the developments of various CNS structures

The mass of the pituitary gland demonstrated an age-dependent increase $(\rho=0.459 ; p<0.05)$. The increase could be best described by an exponential function, yielding a time constant of 1.69 weeks (Fig. 7a). The mean cell number in the pituitary gland also increased with age $(\rho=0.521 ; p<0.01)$ and the change could be fitted to a single exponential function ( $\tau=3.33$ weeks; Fig. $7 \mathrm{~b}$ ). The cell density of the pituitary gland showed weak (but statistically significant) correlation with age $(\rho=0.419 ; p<0.05)$, which could be described by an exponential function ( $\tau=4.68$ weeks). When data from weeks 4-6 and 11-40 were pooled and compared, the mean values proved to be statistically significant $\left(401,000 \pm 25,000\right.$ vs. $524,000 \pm 30,000$ cells $\left.\cdot \mathrm{mg}^{-1} ; p<0.01\right)$. Strong, positive correlation was found between the mass of the pituitary gland and its cell number (Fig. 7c), with a slope of 455,000 cells $\cdot \mathrm{mg}^{-1}$. 
The mass of both spinal cord $(\mathrm{R}=0.634 ; p<0.001)$ and whole brain $(\mathrm{R}=0.563 ; p<0.01)$ showed a good correlation with the number of cells in the pituitary gland (Fig. 7d). When the individual parts of the brain were separately tested, the masses of the cerebellum $(\mathrm{R}=0.633 ; p<0.001)$ and the 'rest of the brain' $(\mathrm{R}=0.493$; $p<0.01)$ correlated well with the pituitary cell number. In addition, the mass and the NeuN negative cell numbers of the spinal cord $(\mathrm{R}=0.524 ; p<0.01)$ and the entire brain $(\mathrm{R}=0.460 ; p<0.05)$ both showed statistically justified correlation with the number of the pituitary cells. Cell numbers in the olfactory bulb also correlated with pituitary cell number with $\mathrm{R}=0.572(p<0.01)$ and $0.629(p<0.001)$ for NeuN negative and NeuN positive cells, respectively.

We looked for correlations between cell numbers of individual structures, especially those whose development is known to be, or may be, associated with each other (e.g., cerebellum-spinal cord or isocortex'rest of the brain'; Watson et al. 2012). The NeuN positive cell numbers of the cerebellum and olfactory bulb showed weak but statistically significant correlation $(\mathrm{R}=0.362 ; p<0.05)$. Good correlations could be established between the NeuN negative cell numbers of the following pairs — isocortex and spinal cord $(\mathrm{R}=0.559 ; p<0.01)$, isocortex and 'rest of the brain' $(\mathrm{R}=0.436 ; p<0.05)$, hippocampus and 'rest of the brain' (0.503; $p<0.01)$, olfactory bulb and spinal cord $(\mathrm{R}=0.605 ; p<0.001)$.

$<$ Fig. 7 is about to be here>

4. Correlation between the masses of CNS structures and their cellular constitution

During the period investigated each milligram increase in mass was associated with a neuronal cell number increase of $\sim 700,000$ in the cerebellum $(\mathrm{R}=0.616), \sim 15,200$ in the hippocampus $(\mathrm{R}=0.621)$, and $\sim 205,000$ in the olfactory bulb $(\mathrm{R}=0.636 ; p<0.001$ in every case). In the hippocampus, a strong correlation exists between the mass and the NeuN negative number as well $(\mathrm{R}=0.713 ; p<0.001 ; \mathrm{B}=59,900)$. As for the possible correlation between mass and some other parameters, the NeuN negative / NeuN positive cell number ratio in the spinal cord increased by $0.023(\mathrm{R}=0.565 ; p<0.001)$; whereas the neuronal and non-neuronal density in the 'rest of the brain' decreased by 156 and 267 cells for each milligram increase in mass, respectively $(\mathrm{R}=-0.650$ and $p<0.001$ for the NeuN positive cell density, whereas $\mathrm{R}=-0.471$ and $p<0.01$ for the NeuN negative cell density). 


\section{Discussion}

In this study, we examined age-related changes associated with postnatal development, maturation, and regression in the mouse CNS. We looked for alterations of the cellular composition (including neuronal and non-neuronal cell numbers and ratios), cell densities, and possible correlations between parameters in different parts of the CNS. We found that the number of non-neuronal cells increased, whereas the number of neuronal cells stayed constant in most regions of the CNS — with the notable exception of the olfactory bulb and cerebellum, where the number of neurons significantly increased between week 4 and week 15. Our present findings clarify the nature of the alterations affecting the cellular composition of mouse CNS during postnatal life and suggest that application of at least 11-week-old mice is advisable in all studies aimed at the investigation of the adult CNS.

1. The dynamic changes in cellular constitution occurring during postnatal development are specific to the different structures in the mouse CNS

It has been known for a long time that the development of the CNS is a heterogeneous process and different rules and rates apply to its individual parts (Altman 1969b; Bayer 1980b, 1983; Kim and Sun 2011). However, it is generally accepted that although there may be considerable changes during the postnatal development of the mouse CNS, the vast majority of neurons are generated in the prenatal-early postnatal period. The present work supports this view, as the number of neurons did not show significant change in 4 of the 6 structures investigated. Surprisingly, we found a net increase in the neuronal number of the olfactory bulb and cerebellum during the period from the 4 to 15 weeks. Despite relatively constant neuronal cell numbers, however, each structure demonstrated certain, and in some cases rather unique, changes during the age period under investigation. These changes are discussed in the next section. To highlight some of the important agedependent changes affecting the cellular organization of the investigated structures, the results of group comparisons performed between mice aged 4-6 and 11-40 weeks are also presented (Fig. 8)

<Fig. 8 is about to be here>

The spinal cord showed a significant increase in mass, which was accompanied with a significant increase of the non-neuronal cell number and a consequent increase of the NeuN negative / NeuN positive cell number ratio. The increase of mass is disproportionately rapid compared to that of the cell number, which results in massively reduced cellular densities for both neuron and non-neuron, including glia (Fig. 8a). This change may be the consequence of an increase in mean neuronal size, axonal extension, and/or myelination. 
The hippocampus showed an impressive increase in mass but the NeuN positive cell number and the NeuN negative / NeuN positive cell number ratio were fairly constant. The NeuN negative cell number showed moderate increase when data obtained from 4-6 and 11-40 week-old groups were compared (Fig. 8b). Consequently, this structure shows a significant reduction in the cell densities, suggesting that alterations of average cell size, including pericellular space, are important parts of the dynamic changes taking place in the hippocampus. Similar observations were made in the rat hippocampus (Bandeira et al. 2009). We could not find any early sign of neuronal cell loss when comparing the relevant parameters obtained from the week 15 and week 40 groups - an observation that coincides with the conclusion drawn by Stranahan et al. (2012).

The isocortex was the only structure without a statistically significant change in mass during the period from week 4 to week 40. Nevertheless, the significant increase of the number and density of non-neuronal cells as well as the subsequent increase of the NeuN negative / NeuN positive cell number ratio probably reflect postnatal generation of glia and the ongoing maturation of the neuronal pathways, which appear to be completed by the $15^{\text {th }}$ week (Fig. 8c). We hypothesize that the surprisingly 'heavy' isocortex noted in the 4-week-old group may be the consequence of the high lipid content associated with the developmental process. In rats, the mass of the isocortex showed an approximately $3 \mu \mathrm{g}$ /day reduction during the $25-55$ days period (Bandeira et al. 2009). This reduction of the mass was accompanied by fairly constant neuronal and non-neuronal cell numbers, densities, and NeuN negative / NeuN positive cell ratio.

We found that the cerebellum contains the most neuronal cells and presents the highest cell density. The most important alteration observed in the cerebellum was the significant increase of the neuronal cell number from week 4 to week 15 (Fig. 8d). Bandeira et al. (2009) have also seen an increase in number of neurons in the cerebellum after birth. It has been suggested that cerebellar cell proliferation reaches its peak during the first week after birth, whereas cell migration and elongation primarily occur during the second postnatal week and become completed by the third week (Matoba et al. 2000). At this point, the cerebellar cortex enters its second phase of development, which involves gradual maturation of synapses, without apparent morphological changes (Matoba et al. 2000). Finally, at the end of this phase, the adult characteristics of the cerebellum are reached (Matoba et al. 2000). The result shown in the current study suggests the neuronal number of the murine cerebellum keeps on increasing till about week 15. Our observation is in harmony with findings pointing out that there are neural stem cells in both the embryonic and adult cerebellum (Klein et al. 2005; Sottile et al. 2006) and demonstrating that these neuronal stem cells are capable of differentiating into cerebellar-specific neurons both in vitro (Klein et al. 2005) and in vivo (Ponti et al. 2010). 
In the olfactory bulb, there is an increase in non-neuronal cell number and a marked increase in neuronal cell number as well (Fig. 8e). A similar observation was made in rats (Bandeira et al. 2009). The net increase of the neuronal cell number is consistent with the well-documented postnatal neurogenesis that contributes to the olfactory bulb cell numbers (Pignatelli and Belluzzi 2010; Mejia-Gervacio et al. 2012; Breton-Provencher and Saghatelyan 2012, Cushman et al. 2012). Lemasson et al. (2005) reported on the presence of two distinct populations of newborn interneurons. 'Early born' granule cells appear between postnatal 3-7 days and they form the larger de novo produced cell population. In contrast, there are 'later born' granule cells, which appear between P14 and P60. These neurons are preferentially present in the deeper portions of the olfactory bulb. About $50 \%$ of the late born neurons are eliminated after their genesis, whereas almost all early born neurons survive until adulthood. Imayoshi et al. (2008) demonstrated the presence of continuous neurogenesis in the adult forebrain, hypothesizing that it is required to maintain and reorganize the interneuron system of the olfactory bulb. In addition, convincing evidence is provided in a recent article underscoring the presence and significance of adult neurogenesis in the olfactory bulb (Cushman et al. 2012).

The 'rest of the brain' demonstrated a significant increase of the non-neuronal cell number (Fig. 8f), resulting in a slightly increased NeuN negative / NeuN positive cell number ratio, which became statistically significant only when the 4 week group was compared to the 40 week group $(p<0.05)$. This alteration accords with the need of the development of various isocortical pathways as well as many other neuronal communication systems (e.g., connections between midbrain and subcortical regions or between the axial hindbrain and cerebellum) and results in a decreased NeuN positive cell density (Fig. 8f). Although similar trends could be noted in rats (i.e., increased non-neuronal cell number and NeuN negative / NeuN positive cell ratio), the relevant changes took place earlier (5-25 postnatal days; Bandeira et al. 2009).

\section{Technical considerations}

The best test of the accuracy of our present data would be a direct comparison with similar cell counting studies in mice, using stereology. However, such studies are rare and they mostly concern the hippocampus. In addition, they fail to offer one of the largest advantages of the isotropic fractionator, which is complete independence of the estimates from structure volume (Herculano-Houzel and Lent 2005). Furthermore, these studies are difficult to compare either with each other or with our data because they vary in respect to the strains, gender, and age of the mice being studied (for details see Table 2).

<Table 2 is about to be here>

When comparing our results with those of Wingert (1969) on NMRI/Orig./Kisslegg mice, considerable 
similarities may be noticed. For example, the mass of the brain of 4- and 6-week-old mice in our study (ranging from 432 to $480 \mathrm{mg}$ and from 448 to $478 \mathrm{mg}$, respectively) was reasonably close to that reported by Wingert (435-532 mg and 471-518 mg in the age-matched groups). In contrast, the body masses are less similar: 13.5$14.6 \mathrm{~g}$ (present work) vs. 17-26 g (Wingert 1969) in 4-week-old, and 19-21 g vs. 26-29 g in 6-week-old mice. This difference may be attributed to interstrain-differences (C57BL/6J vs. NMRI/Orig./Kisslegg) or to external factors known to be capable of affecting growth. Nevertheless, the similar brain size of the two strains implies that the age-dependence of the CNS development and the cell composition-derived parameters reported in our work are not specific to C57BL/6J mice and they may be applicable for different strains, too.

Additionally, it should be noted that Wingert (1969) applied a logistic growth function to describe the agedependence of the mass-gain of the whole brain and its components, whereas we used a single exponential function for the same purpose. However, in the referenced article larger sample size (199 mice) and different age-range (12-170 days from conception) were used - i.e., the embryonic development was also included. Because our work was restricted to the postnatal development (28-280 postnatal days, corresponding to 48-300 days after conception), it is not surprising that the logistic growth function could not be applied to fit our data and we did not see the characteristic sigmoid-shaped distribution of the investigated parameters. In fact, we observed only the 'top half' of the logistic growth curve, which can be well approximated by an exponential function; hence our fitting functions appear to be adequately chosen.

\section{Significance of the present data}

Although the present study is technically similar to that conducted on rat (Bandeira et al. 2009), our data are novel in many aspects. Firstly, the present work has been conducted on C57BL/6J mice — the strain on which most transgenic lines are based. We have determined the neuronal and non-neuronal cell numbers in all major parts of the brain and at different time points of postnatal maturation. The obtained data may be used as reference when describing age- and condition-dependent changes in transgenic strains serving as mouse models of human diseases. Secondly, our present work includes the spinal cord; therefore it helps to understand how the cellular organisation of this part of the CNS changes during the postnatal life. Such data may have specific relevance in all research efforts aimed at the characterisation of motor neuron diseases (e.g., amyotrophic lateral sclerosis). Thirdly, although they are similar in many aspects, rats and mice are not identical and their characteristics cannot be always directly compared. The age-dependence of the development is different in these two species, as is the onset of the 'adult' state. Finally, our present work focused on murine adolescence and therefore helps to understand the nature of changes accompanying the cellular re-organisation of the adolescent 
brain. In addition, to have a better understanding of the changes, alterations affecting the mass and cell number of the pituitary gland were also described.

4. Is there interdependence between the cell numbers of functionally related structures?

Considering the neuronal connections and functional relationships between certain areas (notably between isocortex and spinal cord, isocortex and cerebellum, axial hindbrain and cerebellum, as well as cerebellum and spinal cord), we looked for correlations between the cell numbers of these structures during their postnatal development. We found no obvious correlation between the neuronal numbers of the isocortex and cerebellum but there was a statistically significant correlation between the NeuN positive cell numbers of the cerebellum and olfactory bulb, which is probably coincidence as both structures are in an active developmental phase during the period from 4 to 15 weeks. The lack of correlation between neuronal cell numbers across most CNS structures is not surprising as only the olfactory bulb and cerebellum exhibited an age-dependent increase of the neuronal cell number.

The correlations found between the NeuN negative cell numbers of the isocortex and spinal cord as well as of the isocortex and 'rest of the brain' may reflect a coordinated generation of not only astrocytes but also oligondendroglial cells, which is necessary for the outgrowth of axons running through these structures during the investigated time span. Likewise, the correlations in numbers of NeuN negative cells between the hippocampus and 'rest of the brain' as well as between the olfactory bulb and spinal cord suggest that the postnatal generation of non-neuronal cells (mainly glia) is a generalized event throughout the brain in adolescence.

5. When might be the turning point separating adolescence and adulthood in mice?

We found a statistically significant increase in the mean mass of the pituitary gland between the 4-6 week group and the $11-40$ week group $(p<0.05)$. Moreover, the number of cells in the pituitary gland increased rapidly from week 4 to week 11. By week 11, however, the cell number appeared to stabilize and there was no appreciable change in the pituitary cell number from this time point on. Rather similar observations could be made when the age-dependence of major somatic parameters was studied: the body length and body mass leveled off at about and just after week 11, respectively, terminating the phase of the rapid growth and showing no major changes afterwards. These findings imply that the turning point (or watershed period) in the course of the mouse physical development, separating the period of active growth (i.e., adolescence) from that of a substantially reduced rate of somatic development (corresponding to early adulthood), occurs sometime between 
weeks 8 and 11 .

The concept of a watershed period is supported by other data relating to the development of the CNS. When the relative brain mass and spinal cord length are plotted as a function of age, they both level off at about week 11. The same general rule seems to govern the age-dependence of the mass of some CNS structures, as the rapid phase of mass gain was finished by week 8 (cerebellum) or by week 11 (hippocampus, olfactory bulb, spinal cord, and 'rest of the brain'). Furthermore, a similar watershed could be identified when the age-dependence of the non-neuron numbers of the spinal cord and isocortex was examined, as in both cases two distinct states were observed in the age periods of 4-6 weeks and 11-40 weeks, respectively. It seems reasonable, therefore, to consider the period between the week 8 and week 11 as an important era in development, marking the end of rapid changes in mass and cell number in the mouse CNS, and marking the time when the various structures reach their adult-like states. For this reason, we suggest that 11-week-old or older mice should be the preferred age for studies intended to be performed on 'adult' mice. 


\section{Conflict of interest}

The authors declare that they have no conflict of interest.

\section{Acknowledgements}

This study was supported by an NHMRC (National Health \& Medical Research Council) Australia Fellowship Grant awarded to George Paxinos (Grant \#568605), the Australian Research Council Thinking Systems Initiative (TS0669860), by grants from CNPq (Conselho Nacional de Desenvolvimento Científico e Tecnológico, Brazil), FAPERJ (Fundação de Amparo à Pesquisa do Estado do Rio de Janeiro), INCT/MCT (Instituto Nacional de Ciência e Tecnologia/Ministério de Ciência e Tecnologia), and the James S. McDonnell Foundation to Dr. Suzana Herculano-Houzel. 


\section{REFERENCES}

Altman J (1969a) Autoradiographic and histological studies of postnatal neurogenesis. 3. Dating the time of production and onset of differentiation of cerebellar microneurons in rats. J Comp Neurol 136: 269293

Altman J (1969b) Autoradiographic and histological studies of postnatal neurogenesis. IV. Cell proliferation and migration in the anterior forebrain, with special reference to persisting neurogenesis in the olfactory bulb. J Comp Neurol 137: 433-457

Bandeira F, Lent R, Herculano-Houzel S (2009) Changing numbers of neuronal and non-neuronal cells underlie postnatal brain growth in the rat. Proc Natl Acad Sci U S A 106: 14108-14113

Bayer SA (1980a) Development of the hippocampal region in the rat. I. Neurogenesis examined with $3 \mathrm{H}-$ thymidine autoradiography. J Comp Neurol 190: 87-114

Bayer SA (1980b) Development of the hippocampal region in the rat. II. Morphogenesis during embryonic and early postnatal life. J Comp Neurol 190: 115-134

Bayer SA (1983) ${ }^{3} \mathrm{H}$-thymidine-radiographic studies of neurogenesis in the rat olfactory bulb. Exp Brain Res 50: $329-340$

Bayer SA (1989) Cellular aspects of brain development. Neurotoxicology 10: 307-320

Bonthius DJ, McKim R, Koele L, Harb H, Karacay B, Mahoney J, Pantazis NJ (2004) Use of frozen sections to determine neuronal number in the murine hippocampus and neocortex using the optical disector and optical fractionator. Brain Res Brain Res Protoc 14: 45-57

Breton-Provencher V, Saghatelyan A (2012) Newborn neurons in the adult olfactory bulb: Unique properties for specific odor behavior. Behav Brain Res 227:480-489

Coulin C, Drakew A, Frotscher M, Deller T (2001) Stereological estimates of total neuron numbers in the hippocampus of adult reeler mutant mice: Evidence for an increased survival of Cajal-Retzius cells. $\mathbf{J}$ Comp Neurol 439: 19-31

Cushman JD, Maldonado J, Kwon EE, Garcia AD, Fan G, Imura T, Sofroniew MV, Fanselow MS (2012) Juvenile neurogenesis makes essential contributions to adult brain structure and plays a sex-dependent role in fear memories. Frontiers Behav Neurosci 6:3

Drage MG, Holmes GL, Seyfried TN (2002) Hippocampal neurons and glia in epileptic EL mice. J Neurocytol 31: 681-692

Drickamer, LC (1981) Selection for age of sexual maturation in mice and the consequences for population regulation. Behav Neural Biol 31: 82-89

Flood DG, Coleman PD (1988) Neuron numbers and sizes in aging brain: comparisons of human, monkey, and rodent data. Neurobiol Aging 9: 453-463

Fox, JG, Barthold, S, Davisson, M, Newcomer, CE, Quimby, FW, Smith, A (2006) The mouse in biomedical research. Academic Press, Burlington, MA

Haddara M (1956) A quantitative study of the postnatal changes in the packing density of the neurons in the visual cortex of the mouse. J Anat 90: 494-501

Herculano-Houzel S, Lent R (2005) Isotropic fractionator: a simple, rapid method for the quantification of total cell and neuron numbers in the brain. J Neurosci 25: 2518-2521

Hong SM, Liu Z, Fan Y, Neumann M, Won SJ, Lac D, Lum X, Weinstein PR, Liu J (2007) Reduced hippocampal neurogenesis and skill reaching performance in adult Emx1 mutant mice. Exp Neurol 206: $24-32$

Imayoshi I, Sakamoto M, Ohtsuka T, Takao K, Miyakawa T, Yamaguchi M, Mori K, Ikeda T, Itohara S, Kageyama R (2008) Roles of continuous neurogenesis in the structural and functional integrity of the adult forebrain. Nature Neurosci 11: 1153-1161

Kempermann G, Kuhn HG, Gage FH (1997) More hippocampal neurons in adult mice living in an enriched environment. Nature 386: 493-495 
Kim WR, Sun W (2011) Programmed cell death during postnatal development of the rodent nervous system. Dev Growth Differ 53: 225-235

Klein C, Butt SJB, Machold RP, Johnson JE, Fishell G (2005) Cerebellum- and forebrain-derived stem cells possess intrinsic regional character. Development 132: 4497-4508

Koek W, France CP, Javors MA (2012) Morphine-induced motor stimulation, motor incoordination, and hypothermia in adolescent and adult mice. Psychopharmacology (Berl) 219: 1027-1037

Lemasson M, Saghatelyan A, Olivo-Marin J-C, Lledo P-M (2005) Neonatal and adult neurogenesis provide two distinct populations of newborn neurons to the mouse olfactory bulb. J Neurosci 25: 6816-6825.

Long JM, Kalehua AN, Muth NJ, Calhoun ME, Jucker M, Hengemihle JM, Ingram DK, Mouton PR (1998) Stereological analysis of astrocyte and microglia in aging mouse hippocampus. Neurobiol Aging 19: 497-503

Lyck L, Kroigard T, Finsen B (2007) Unbiased cell quantification reveals a continued increase in the number of neocortical neurones during early post-natal development in mice. Eur J Neurosci 26: 1749-1764

Matoba R, Saito S, Ueno N, Maruyama C, Matsubara K, Kato K (2000) Gene expression profiling of mouse postnatal cerebellar development. Physiol Genomics 4: 155-164

Mejia-Gervacio S, Murray K, Sapir T, Belvindrah R, Reiner O, Lledo PM (2012) MARK2/Par-1 guides the directionality of neuroblasts migrating to the olfactory bulb. Mol Cell Neurosci 49:97-103

Mouton PR, Long JM, Lei DL, Howard V, Jucker M, Calhoun ME, Ingram DK (2002) Age and gender effects on microglia and astrocyte numbers in brains of mice. Brain Res 956: 30-35

Mullen RJ, Buck CR, Smith AM (1992) NeuN, a neuronal specific nuclear protein in vertebrates. Development 116: $201-211$

Paxinos G, Halliday G, Watson C, Koutcherov Y, Wang HQ (2007) Atlas of the devloping mouse brain at E17.5, P0, and P6. Elsevier Academic Press, San Diego

Pignatelli A, Belluzzi O (2010) Chapter 11 In: Menini A (ed). Neurogenesis in the Adult Olfactory Bulb. Boca Raton (FL): CRC Press, Frontiers in Neuroscience

Ponti G, Crociara P, Armentano M, Bonfanti L (2010) Adult neurogenesis without germinal layers: the "atypical" cerebellum of rabbits. Arch Ital Biol 148: 147-158.

Quoilin C, Didone V, Tirelli E, Quertemont E (2012) Developmental differences in ethanol-induced sensitization using postweanling, adolescent, and adult Swiss mice. Psychopharmacology (Berl) 2012: 1165-1177

Royet JP, Distel H, Hudson R, Gervais R (1998) A re-estimation of the number of glomeruli and mitral cells in the olfactory bulb of rabbit. Brain Res 788: 35-42

Sisk CL, Foster DL (2004) The neural basis of puberty and adolescence. Nat Neurosci 7: 1040-1047

Sottile V, Li M, Scotting PJ (2006) Stem cell marker expression in the Bergmann glia population of the adult mouse brain. Brain Res 1099: 8-17

Stranahan AM, Jiam NT, Spiegel AM, Gallagher M (2012) Aging reduces total neuron number in the dorsal component of the rodent prefrontal cortex. J Comp Neurol 520: 1318-1326

Vandenbergh, J G (1987) Regulation of puberty and its consequences on population dynamics of mice. Am Zool 27: 891-898

Watson, C, Paxinos, G, Puelles, L (2012) The mouse nervous system. Elsevier Academic Press, San Diego

Wingert, F (1969) Biometrische Analyse der Wachstumsfunktionen von Hirnteilen und Körpergewicht der Albinomaus. J Hirnforschung 11: 133-197.

Witgen BM, Lifshitz J, Grady MS (2006) Inbred mouse strains as a tool to analyze hippocampal neuronal loss after brain injury: a stereological study. J Neurotrauma 23: 1320-1329

Wittmann W, McLennan IS (2011) The male bias in the number of Purkinje cells and the size of the murine cerebellum may require Mullerian inhibiting substance/anti-Mullerian hormone. J Neuroendocrinol 23: 831-838 
Wolf HK, Buslei R, Schmidt-Kastner R, Schmidt-Kastner PK, Pietsch T, et al. (1996) NeuN: a useful neuronal marker for diagnostic histopathology. J Histochem Cytochem 44: 1167-1171 


\section{Figure legends}

Fig. 1 Macroscopic and microscopic views of the structures considered in this study. (a) Gross view of the dissected parts of the mouse central nervous system. (b) Microscopic views of cell nuclei as seen in samples taken from each homogenized structure. Arrows indicate a few examples of DAPI positive (blue) and NeuN positive (red) neuronal nuclei, whereas arrowheads demonstrate a few DAPI positive but NeuN negative structures, identified as non-neuronal cell nuclei. Scale bars $=5 \mathrm{~mm}$ (a); $20 \mu \mathrm{m}$ (b).

Fig. 2 Age-dependence of somatic and neural parameters characterizing the postnatal development of the mouse CNS. (a) Age-dependence of body mass. (b) Age-dependence of body and spinal cord lengths. (c-d) Agedependence of the mass of each investigated structure isolated from the mouse CNS. (e) Interrelation between the mass of the spinal cord and that of the brain. (f) Age-dependence of the relative brain mass. In panels a-d and $\mathrm{f}$, results are given as mean \pm S.E.M; $\mathrm{n}=5$ in every age group. If the scatter is not visible, it is smaller than the diameter of the symbol. Parameters obtained from the 15-week-old group were compared to those yielded from 4- and 40-week-old ones, and the level of significance characterizing the corresponding pairs is indicated. \#\#: $p<0.01 ; * * *: p<0.001$; NS: non-significant. If no significance is indicated, neither comparison resulted in significant difference. The age-dependence ( $a-d$ and $f$ ) and interdependence (e) of the various parameters were characterized by determining the Pearson's $(R)$ or the Spearman's $(\rho)$ coefficients, which are also indicated. In the cases of exponential fits, the time constants $(\tau)$ obtained by the fits are also shown.

Fig. 3 Age-dependent changes in the cellular composition of the spinal cord. (a) Age-dependence of the neuronal and non-neuronal cell numbers. The difference between the NeuN negative cell numbers obtained from the 4- and 40-week old groups is statistically significant $(p<0.05)$. (b) Age-dependence of the NeuN negative / NeuN positive cell number ratio of the spinal cord. (c) Age-dependence of the density of NeuN positive and NeuN negative cells. In $(\mathrm{a}-\mathrm{c})$, all results are given as mean \pm S.E.M; $\mathrm{n}=5$ in each age group. Parameters obtained from the 15 weeks old group were compared to those yielded from 4- and 40-week-old ones and the level of significance characterizing the corresponding pairs is indicated. \#,*: $p<0.05 ; * *: p<0.01$; ***: $p<0.001$; NS: not significant. If no significance is indicated, neither comparison resulted in significant difference. (d) Correlation between the mass and the NeuN positive density of the spinal cord. Data representing all animals are plotted; the same symbol denotes mice belonging to the same age group. The age-dependence $(a-c)$ and interdependence $(d)$ of the various parameters were characterized by determining the Pearson's (R) or 
the Spearman's $(\rho)$ coefficients, which are also indicated. In the cases of exponential fits, the time constants $(\tau)$ obtained by the fits are also shown.

Fig. 4 Age-dependent changes characterizing the cellular composition of the isocortex. (a) Age-dependence of the neuronal and non-neuronal cell numbers. (b) Age-dependence of the density of NeuN positive and NeuN negative cell numbers. (c) Age-dependence of the NeuN negative / NeuN positive cell number ratio in the isocortex. Results are given as mean \pm S.E.M; $n=5$ in every age group. Parameters obtained from the 15 weeks old group were compared to those yielded from 4- and 40-week-old ones and the level of significance characterizing the corresponding pairs is indicated. *: $p<0.05 ; * *: \mathrm{p}<0.01$; NS: not significant. If no significance is indicated, neither comparison resulted in significant difference. The age-dependence of the various parameters was characterized by determining the Spearman's coefficients $(\rho)$, which are also indicated. In the cases of the exponential fits, the time constants $(\tau)$ are also shown.

Fig. 5 Age-dependent changes characterizing the cellular composition of the cerebellum, hippocampus, and olfactory bulb. (a1) Age-dependence of the neuronal and non-neuronal cell numbers of the cerebellum. (a2) Age-dependence of the neuronal and non-neuronal cell densities of the cerebellum. (b) Age-dependence of the neuronal and non-neuronal cell numbers in the hippocampus. (c) Age-dependence of the neuronal and nonneuronal cell numbers in the olfactory bulb. The age-dependence was characterized by determining the Pearson's (R) or the Spearman's $(\rho)$ coefficients, which are also indicated. In the cases of the exponential fits, the time constants $(\tau)$ are also shown. In all panels, results are given as mean \pm S.E.M; $n=5$ in every age group. Parameters obtained from the 15 weeks old group were compared to those yielded from 4- and 40-week-old ones and the level of significance characterizing the corresponding pairs is indicated. *: $p<0.05 ; * *: p<0.01$; NS: not significant. If no significance is indicated, neither comparison resulted in significant difference.

Fig. 6 Age-dependent changes characterizing the cellular composition of the 'rest of the brain'. (a) Agedependence of the neuronal and non-neuronal cell numbers. (b) Age-dependence of the density of NeuN positive and NeuN negative cells. (c) Age-dependence of the NeuN negative / NeuN positive cell number ratio in the 'rest of the brain'. Results are given as mean \pm S.E.M; $n=5$ in every age group. Parameters obtained from the 15 weeks old group were compared to those yielded from 4- and 40-week-old ones and the level of significance characterizing the corresponding pairs is indicated. $*: p<0.05 ; * *: p<0.01$; NS: not significant. If no significance is indicated, neither comparison resulted in significant difference. The age-dependence of the 
various parameters was characterized by determining the Spearman's coefficients $(\rho)$, which are also indicated. The time constants associated with each exponential fit are also provided $(\tau)$.

Fig. 7 Age dependent changes of the cellular composition of the pituitary gland and interrelations between the developments of different regions. Age dependence of the mass (a) and cell number (b) of the pituitary gland. Results are given as mean \pm S.E.M; $\mathrm{n}=5$ in every age group. ${ }^{*}: p<0.05$. In the case of the pituitary cell number, comparison of the 5- and 40-week-old groups resulted in a $p$ of 0.051 . The age-dependence of the various parameters was characterized by determining the Spearman's coefficients $(\rho)$, which are also indicated. The time constants associated with each exponential fit are also provided $(\tau)$. (c) Correlation between the mass and the number of cells in the pituitary gland. (d) Correlation between the pituitary cell number and the masses of the spinal cord and brain. In panels $\mathrm{c}-\mathrm{d}$, data representing all animals are plotted. The relevant Pearson's coefficients (R) are also indicated.

Fig. 8 Pooled group comparisons performed between mice aged 4-6 and 11-40 weeks. (a) Spinal cord; NeuN negative cell number (left) and NeuN positive cell density (right). (b) Hippocampus; NeuN positive (left) and NeuN negative (right) cell numbers. (c) Isocortex; NeuN negative cell number (left) and density (right). (d) Cerebellum; NeuN positive (left) and NeuN negative (right) cell numbers. (e) Olfactory bulb; NeuN positive cell number (left) and density (right). (f) 'Rest of the brain'; NeuN negative cell number (left) and NeuN positive cell density (right). The bars were obtained by pooling the relevant data. In all cases, mean \pm S.E.M. are presented. NS: Not significant; *: $\mathrm{p}<0.05 ; * *$ : $<0.01$; and $* * *$ p $<0.001$. 
Click here to download high resolution image
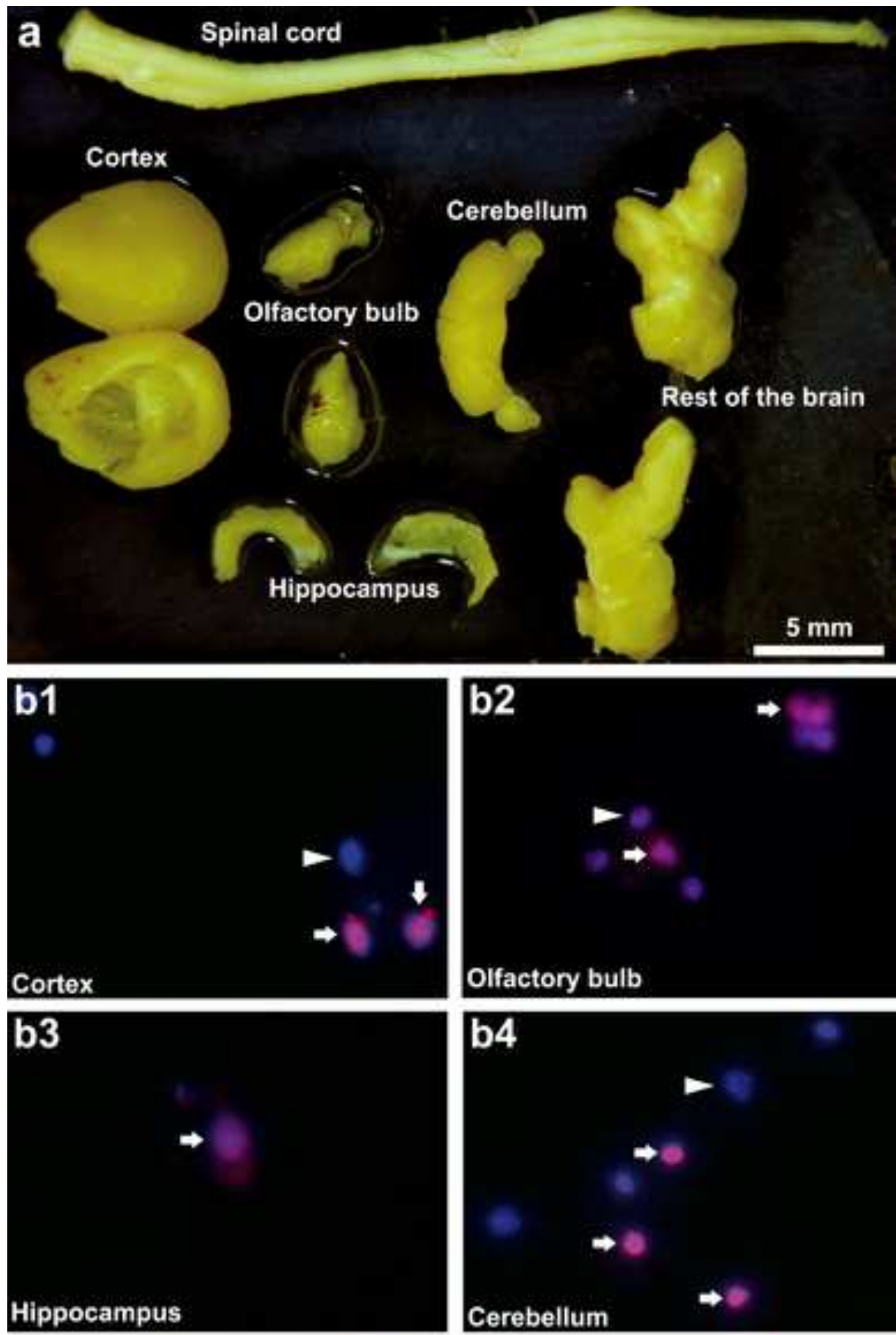

Olfactory bulb
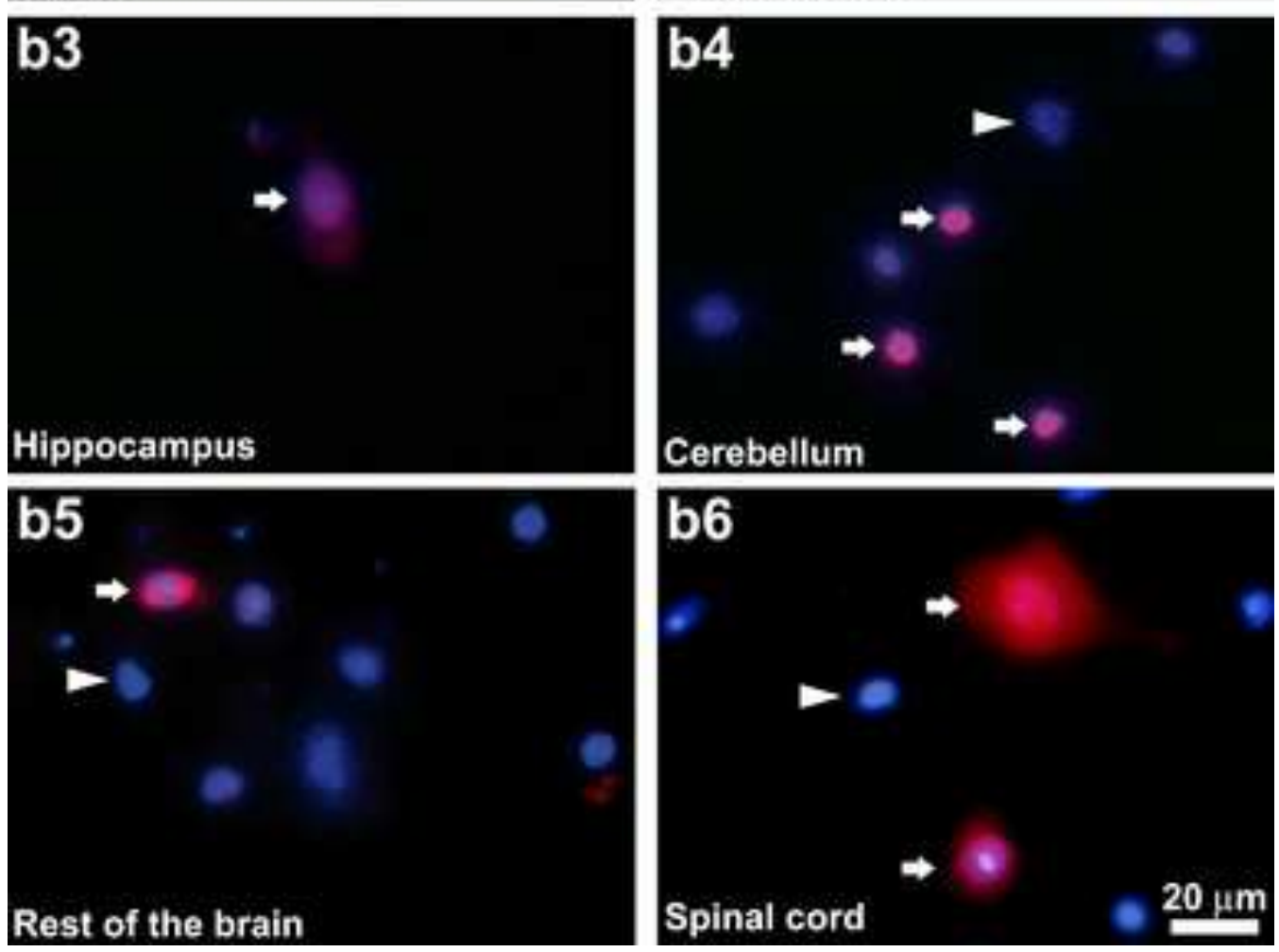

$s$

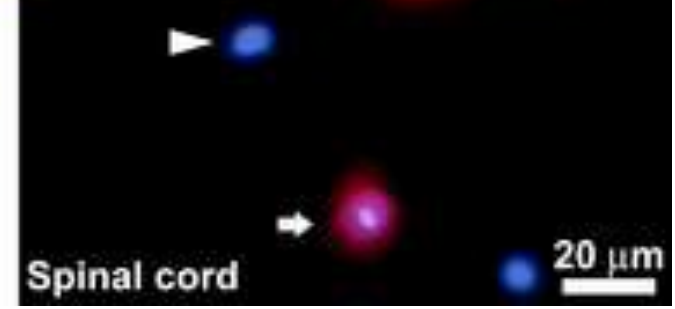


Figure 2

Click here to download high resolution image


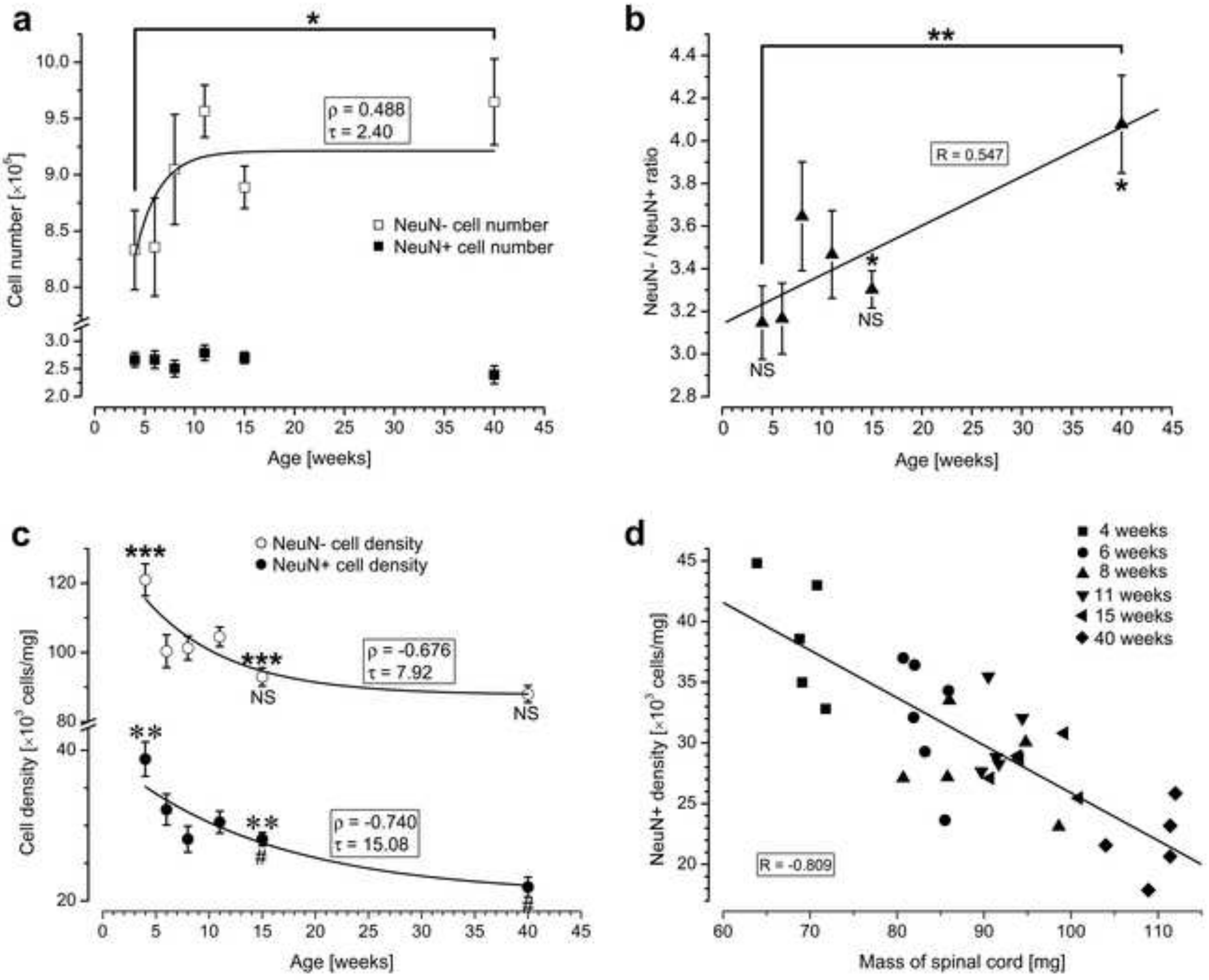
Figure 4

Click here to download high resolution image


Contex 

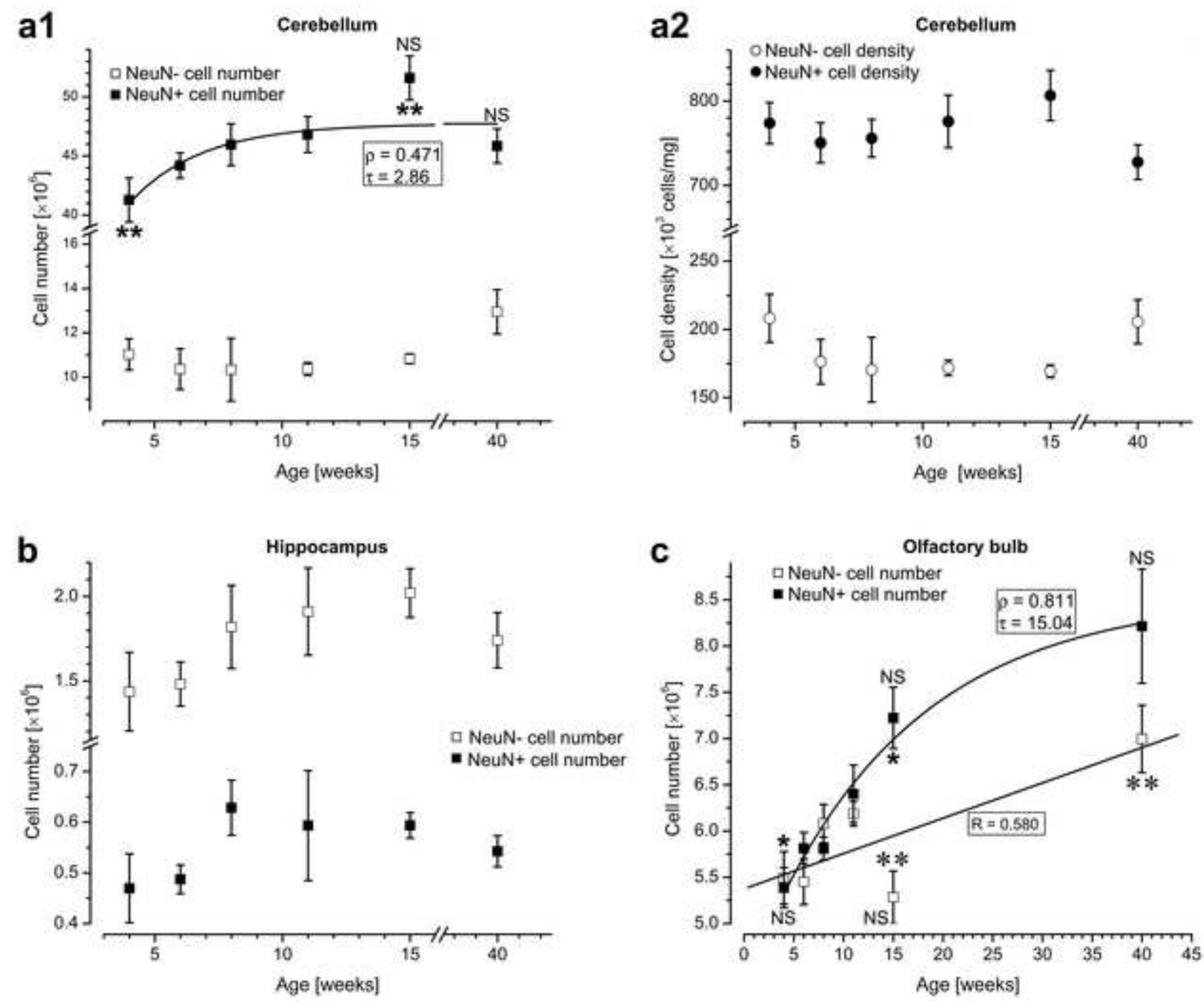
Figure 6

Click here to download high resolution image
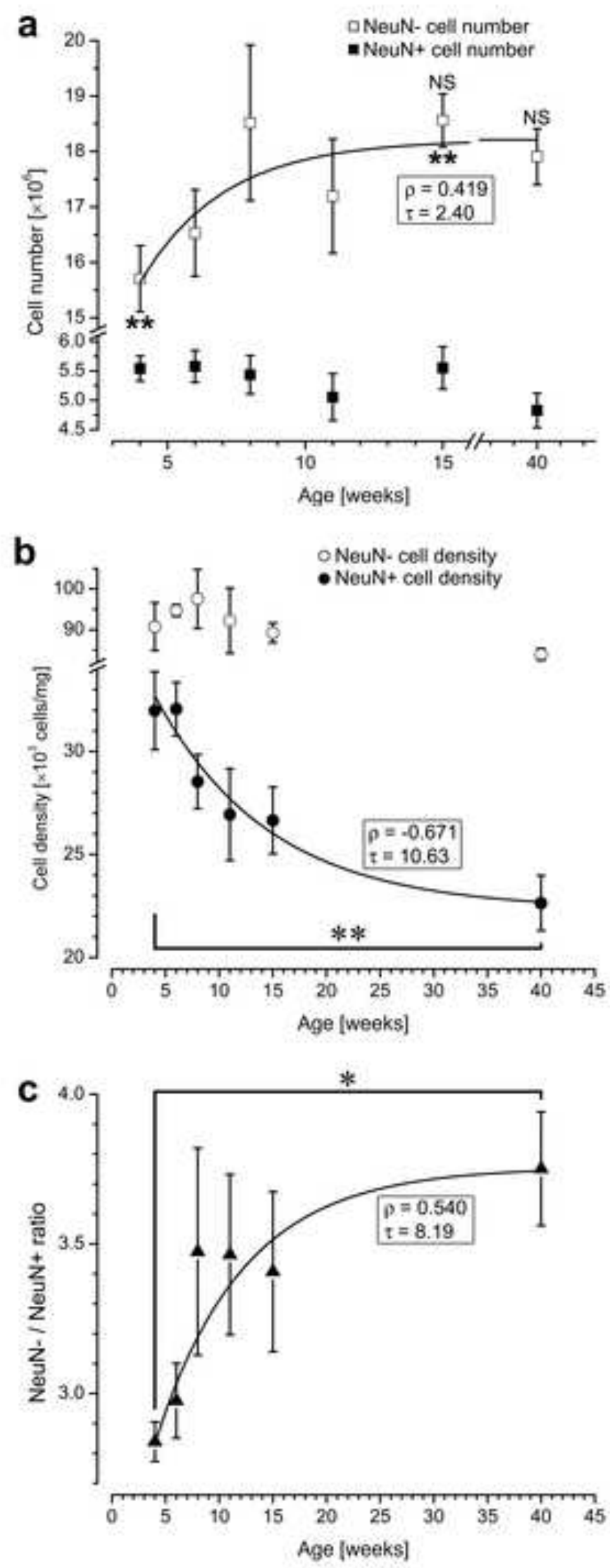

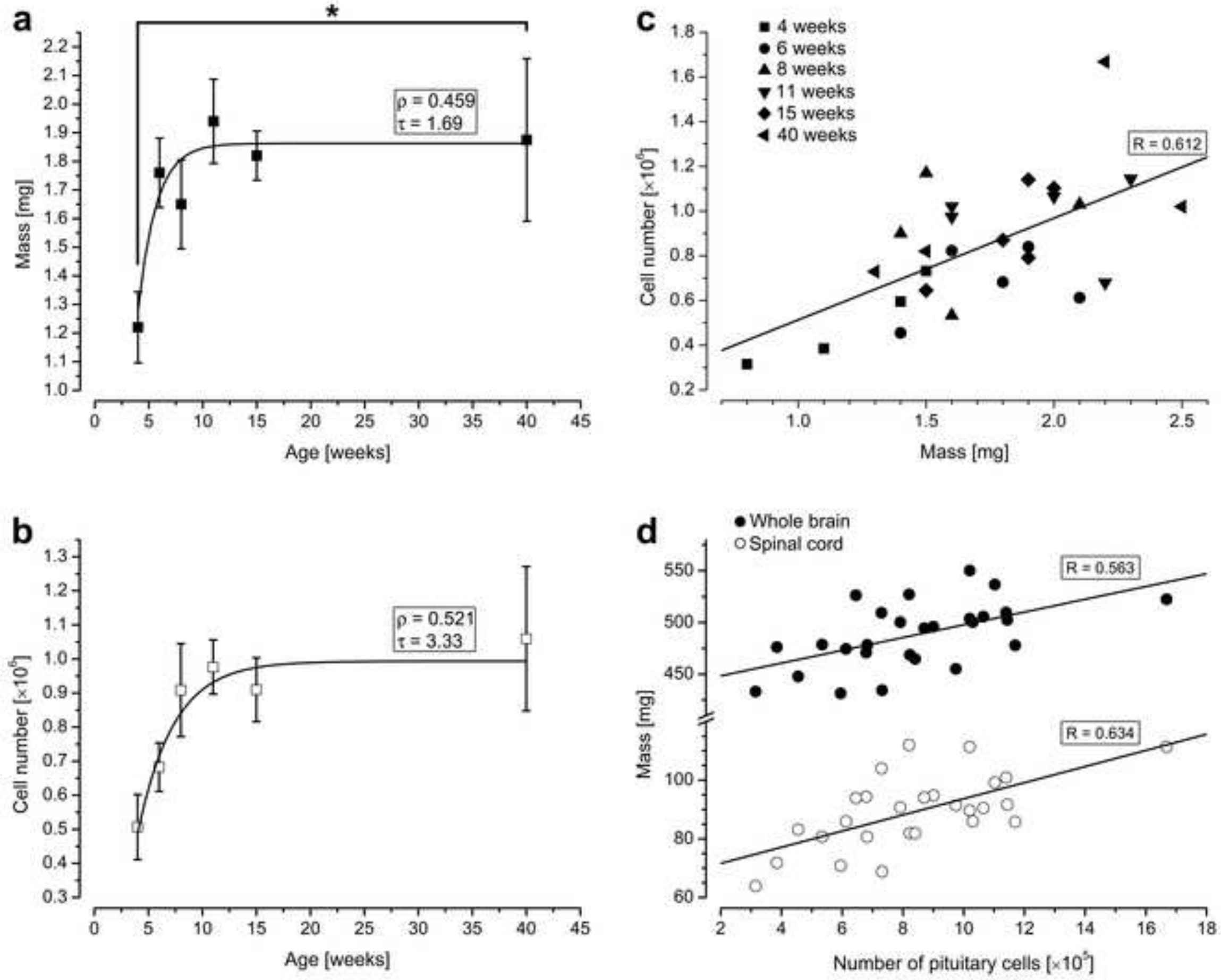



C



e

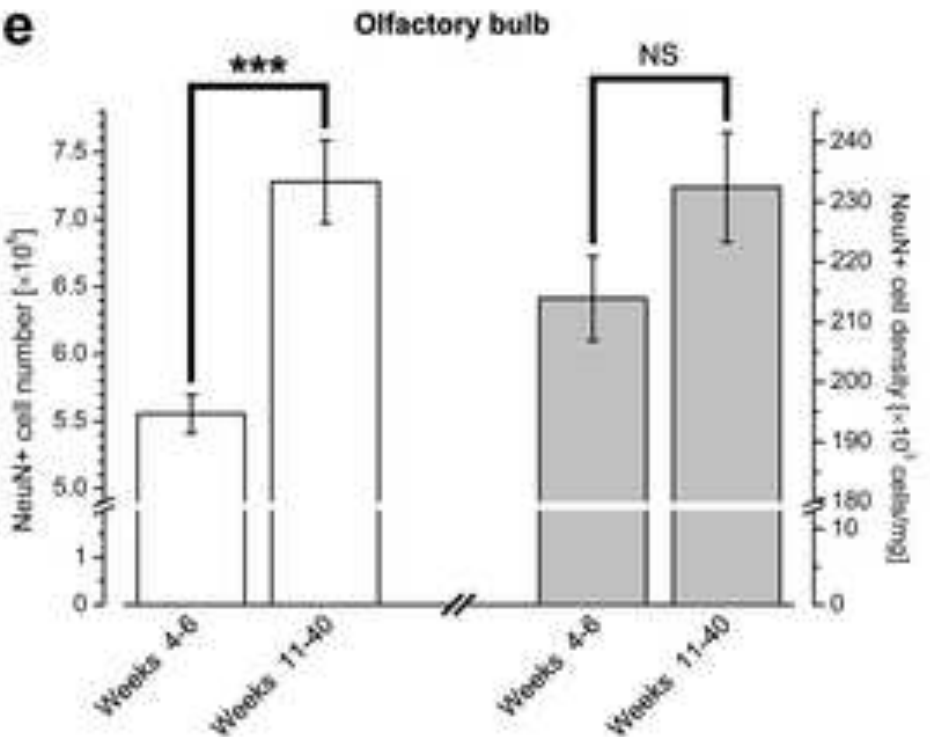

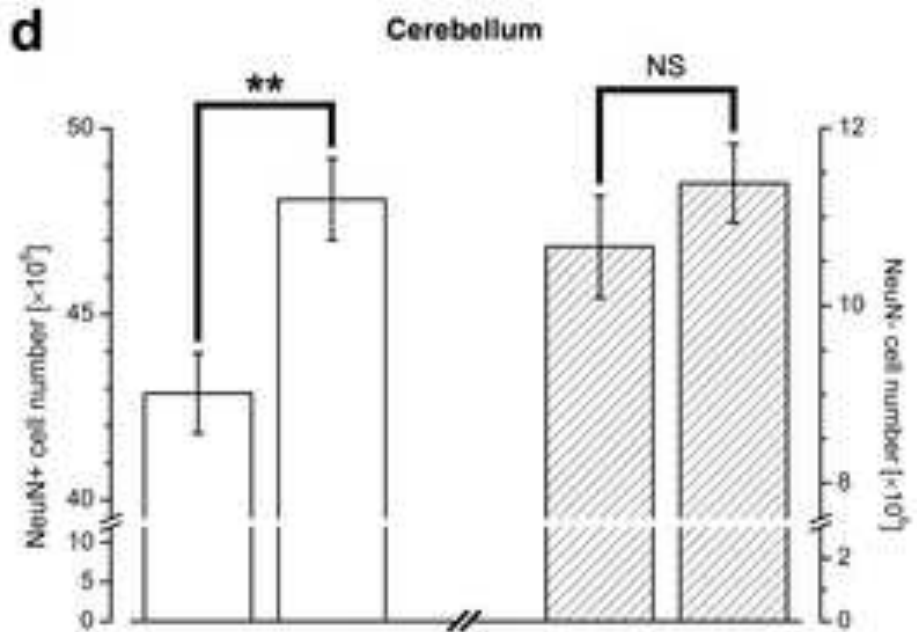

f




Table 1

Age-dependent changes affecting the mouse central nervous system and pituitary

\begin{tabular}{|c|c|c|c|c|c|c|c|c|c|c|c|c|c|c|c|c|c|c|}
\hline \multirow{2}{*}{ Structure } & \multicolumn{3}{|c|}{ Mass } & \multicolumn{3}{|c|}{ Number of neurons } & \multicolumn{3}{|c|}{$\begin{array}{l}\text { Number of non- } \\
\text { neurons }\end{array}$} & \multicolumn{3}{|c|}{ Density of neurons } & \multicolumn{3}{|c|}{$\begin{array}{l}\text { Density of non- } \\
\text { neurons }\end{array}$} & \multicolumn{3}{|c|}{ NN/N ratio* } \\
\hline & $4-15$ & $15-40$ & $4-40$ & $4-15$ & $15-40$ & $4-40$ & $4-15$ & $15-40$ & $4-40$ & $4-15$ & $15-40$ & $4-40$ & $4-15$ & $15-40$ & $4-40$ & $4-15$ & $15-40$ & $4-40$ \\
\hline Isocortex & - & - & - & - & - & - & $\uparrow$ & - & $\uparrow \uparrow$ & - & - & - & $\uparrow$ & - & - & $\uparrow$ & - & $\uparrow \uparrow$ \\
\hline $\begin{array}{l}\text { Olfactory } \\
\text { bulb }\end{array}$ & $\uparrow \uparrow$ & - & $\uparrow \uparrow$ & $\uparrow$ & - & $\uparrow \uparrow$ & - & $\uparrow \uparrow$ & $\uparrow$ & - & - & - & $\downarrow \downarrow$ & $\downarrow \downarrow$ & - & $\downarrow \downarrow$ & - & - \\
\hline $\begin{array}{l}\text { Rest of the } \\
\text { brain }\end{array}$ & $\uparrow \uparrow$ & - & $\uparrow \uparrow$ & - & - & - & $\uparrow \uparrow$ & - & $\uparrow$ & - & - & $\downarrow \downarrow$ & - & - & - & - & - & $\uparrow$ \\
\hline Spinal cord & $\uparrow \uparrow \uparrow$ & $\uparrow \uparrow \uparrow$ & $\uparrow \uparrow \uparrow$ & - & - & - & - & - & $\uparrow$ & $\downarrow \downarrow$ & $\downarrow$ & $\downarrow \downarrow \downarrow$ & $\downarrow \downarrow \downarrow$ & - & $\downarrow \downarrow \downarrow$ & - & $\uparrow$ & $\uparrow \uparrow$ \\
\hline
\end{tabular}

\#: In the case of the pituitary gland, these columns refer to the pituitary cell number and density.

*: Non-neuron / neuron ratio (i.e., NeuN negative / NeuN positive cell ratio)

NA: not applicable

Comparisons were made between the 4-15, 15-40, and 4-40 weeks old groups, each group contained 5 mice (one-way ANOVA with Tukey post-hoc test). Only the statistically significant changes are listed, the direction of the arrows indicates the nature of change ( $\uparrow:$ increase; $\downarrow:$ decrease).

Three arrows: $p<0.001$; Two arrows: $p<0.01$; One arrow: $p<0.05$ 
Table 2

Comparison of the published hippocampal cell numbers with those of the present study

\begin{tabular}{|c|c|c|c|c|c|c|c|c|c|c|c|c|}
\hline \multirow{2}{*}{$\begin{array}{l}\text { Referenced } \\
\text { article }\end{array}$} & \multirow{2}{*}{$\begin{array}{l}\text { Mouse } \\
\text { strain }\end{array}$} & \multirow[b]{2}{*}{ Gender } & \multirow[b]{2}{*}{ Age } & \multirow{2}{*}{$\begin{array}{l}{ }^{8} \text { Subregions } \\
\text { considered }\end{array}$} & \multirow{2}{*}{$\begin{array}{l}\text { Staining } \\
\text { method }\end{array}$} & \multirow[b]{2}{*}{ Counting method } & \multicolumn{3}{|c|}{ Cell numbers reported in the referenced work } & \multicolumn{3}{|c|}{${ }^{8}$ Corresponding cell numbers in our study } \\
\hline & & & & & & & $\begin{array}{c}\text { Total cell } \\
\text { number }\end{array}$ & $\begin{array}{c}\text { Neuronal } \\
\text { number }\end{array}$ & $\begin{array}{c}\text { Non-neuronal } \\
\text { number }\end{array}$ & $\begin{array}{c}\text { Total cell } \\
\text { number }\end{array}$ & $\begin{array}{c}\text { Neuronal } \\
\text { number }\end{array}$ & $\begin{array}{c}\text { Non-neuronal } \\
\text { number }\end{array}$ \\
\hline $\begin{array}{l}\text { Coulin et } \\
\text { al., } 2001\end{array}$ & $\begin{array}{c}\text { Reeler and } \\
\text { control } \\
\text { mice; strain } \\
\text { of origin is } \\
\text { not } \\
\text { mentioned } \\
\end{array}$ & $\sigma^{\nearrow}$, 우 & Adult & $\begin{array}{c}\text { CA1, CA3, } \\
\text { DG }^{\#}\end{array}$ & Nissl stain & $\begin{array}{c}\text { Optical } \\
\text { fractionator } \\
\text { combined with } \\
\text { Optical disector } \\
\text { (Stereo } \\
\text { Investigator) }\end{array}$ & & $2.3 \times 10^{6} *$ & & $2.3-2.6 \times 10^{6}$ & $\begin{array}{c}0.54- \\
0.59 \times 10^{6}\end{array}$ & \\
\hline $\begin{array}{l}\text { Witgen et } \\
\text { al., } 2006\end{array}$ & C57BL/6J & $0^{\top}$ & $\begin{array}{c}\text { Adult } \\
(5-7 \\
\text { weeks) } \\
\end{array}$ & $\begin{array}{c}\text { CA1, CA3, } \\
\text { hilus, DG }\end{array}$ & Nissl stain & Optical disector & & $\begin{array}{l}\text { 762,645/one } \\
\text { side* }\end{array}$ & & $\begin{array}{c}1.89- \\
2.45 \times 10^{6} \\
\end{array}$ & $\begin{array}{c}0.47- \\
0.63 \times 10^{6}\end{array}$ & \\
\hline $\begin{array}{l}\text { Witgen et } \\
\text { al., } 2006\end{array}$ & C57BL/10J & $\sigma^{x}$ & $\begin{array}{c}\text { Adult } \\
(5-7 \\
\text { weeks) }\end{array}$ & $\begin{array}{c}\text { CA1, CA3, } \\
\text { hilus, DG }\end{array}$ & Nissl stain & Optical disector & & $\begin{array}{l}\text { 727,579/one } \\
\text { side* }\end{array}$ & & $\begin{array}{c}1.89- \\
2.45 \times 10^{6} \\
\end{array}$ & $\begin{array}{c}0.47- \\
0.63 \times 10^{6} \\
\end{array}$ & \\
\hline $\begin{array}{l}\text { Bonthius } \\
\text { et al., } 2004\end{array}$ & $\begin{array}{c}\mathrm{F} 2 \\
\text { offspring of } \\
129 \mathrm{SVj} \times \\
\mathrm{B} 6\end{array}$ & $\sigma^{7}$, 우 & $\begin{array}{l}\text { Younger } \\
\text { than } 10 \\
\text { days }\end{array}$ & $\begin{array}{c}\text { CA1, CA3, } \\
\text { DG }\end{array}$ & $\begin{array}{c}\text { Cresyl } \\
\text { violet and } \\
\text { Safranin O }\end{array}$ & $\begin{array}{c}\text { Optical } \\
\text { fractionator } \\
\text { combined with } \\
\text { Optical disector } \\
\text { (Stereo } \\
\text { Investigator) }\end{array}$ & & $\begin{array}{c}0.9 \times 10^{6} / \text { right } \\
\text { hemisphere }\end{array}$ & & & $\begin{array}{l}\text { Not directly } \\
\text { comparable } \\
\left(0.47 \times 10^{6}\right)\end{array}$ & \\
\hline $\begin{array}{l}\text { Drage et } \\
\text { al., } 2002\end{array}$ & C57BL/6J & NS & $\begin{array}{c}\text { Adult } \\
(\sim 12 \\
\text { months })\end{array}$ & $\begin{array}{c}\text { Dorsal } \\
\text { hippocamp } \\
\text { us }\end{array}$ & Nissl stain & Optical disector & & $\begin{array}{c}1,348 \\
\text { neurons } / 30 \mu \mathrm{m} \\
\text { of dorsal } \\
\text { hippocampus* }\end{array}$ & & & $\begin{array}{l}\text { Not directly } \\
\text { comparable }\end{array}$ & \\
\hline $\begin{array}{c}\text { Kemperma } \\
\text { nn et al., } \\
1997 \\
\end{array}$ & C57BL/6J & 우 & 3 months & $\begin{array}{c}\text { DG, } \\
\text { granule } \\
\text { cells }\end{array}$ & Hoechst dye & $\begin{array}{c}\begin{array}{c}\text { Optical disector } \\
\text { (Stereo } \\
\text { Investigator) }\end{array} \\
\end{array}$ & & 270,000 & & & $\begin{array}{c}\text { Not directly } \\
\text { comparable } \\
(600,000)\end{array}$ & \\
\hline $\begin{array}{l}\text { Hong et } \\
\text { al., } 2007\end{array}$ & $\begin{array}{c}\text { C57BL/6J } \\
\text { after } 28 \\
\text { days } \\
\text { behavioral } \\
\text { training } \\
\end{array}$ & NS & $\begin{array}{c}3-4 \\
\text { months }\end{array}$ & $\begin{array}{l}\text { DG, } \\
\text { granule } \\
\text { cells }\end{array}$ & Hoechst dye & $\begin{array}{c}\text { Optical } \\
\text { fractionator } \\
\text { (Stereo } \\
\text { Investigator) }\end{array}$ & & $732,000 / \mathrm{DG}$ & & & $\begin{array}{c}\text { Not directly } \\
\text { comparable } \\
(600,000)\end{array}$ & \\
\hline $\begin{array}{l}\text { Long et al., } \\
\quad 1998\end{array}$ & C57BL/6J & $\sigma^{7}$ & $\begin{array}{c}4-6 \\
\text { months }\end{array}$ & $\begin{array}{l}\text { CA1, DG, } \\
\text { Hilus }\end{array}$ & $\begin{array}{l}\text { IHC (Mac- } \\
1, \text { GFAP) }\end{array}$ & $\begin{array}{c}\text { Optical } \\
\text { fractionator } \\
\text { combined with } \\
\text { Optical disector }\end{array}$ & & & $\begin{array}{c}0.25 \times 10^{6} \\
\text { (astrocyte and } \\
\text { microglia) }\end{array}$ & & & $\begin{array}{c}\text { Not directly } \\
\text { comparable } \\
\left(1.7-2.0 \times 10^{6}\right)\end{array}$ \\
\hline $\begin{array}{l}\text { Mouton et } \\
\text { al., } 2002\end{array}$ & C57BL/6J & $\sigma^{\urcorner}$, 우 & $\begin{array}{c}3-4 \\
\text { months }\end{array}$ & CA1, DG & $\begin{array}{l}\text { IHC (Mac- } \\
1, \text { GFAP) }\end{array}$ & $\begin{array}{l}\text { Optical } \\
\text { fractionator } \\
\text { (Stereologer) }\end{array}$ & & & $\begin{array}{c}0.30 \times 10^{6}(\text { 우 }) \\
0.23 \times 10^{6}\left(\sigma^{7}\right) \\
-(\text { astrocyte } \\
\text { and microglia })\end{array}$ & & & $\begin{array}{c}\text { Not directly } \\
\text { comparable } \\
\left(1.9-2.0 \times 10^{6}\right)\end{array}$ \\
\hline
\end{tabular}

The numbers in this table often represent data ranges, especially when no precise numbers are provided but the cell numbers had to be assessed on the basis of the figures. ${ }^{\S}$ Only parts of the hippocampus were considered in the referenced articles, whereas in our study the cell numbers always refer to the entire hippocampus (both sides).

NS: not specified; ${ }^{\#}$ DG: dentate gyrus

*Nissl staining was used for counting neurons, thus the presented numbers may include a substantial amount of non-neuronal cells - i.e., they may reflect total rather than neuronal cell numbers. 